\section{JOLANTA MOROZIŃSKA-GOGOL}

Wydział Nauk o Zdrowiu

Akademia Pomorska w Stupsku

Bohaterów Westerplatte 64, 76-200 Słupsk

E-mail: jolanta.morozinska-gogol@apsl.edu.pl

\title{
TOXOPLASMA GONDII W ŚRODOWISKU MORSKIM
}

\section{WSTEP}

Toxoplasma gondii (Nicolle et Manceaux, 1908) jest rozpowszechnionym na całym świecie wewnątrzkomórkowym pasożytem zwierzat stałocieplnych. Kluczowa rolę w jego cyklu życiowym pełnia kotowate, będące jedynym żywicielem ostatecznym. Rolę żywicieli pośrednich i paratenicznych (rezerwowych) pełni wiele gatunków ssaków i ptaków, zarówno domowych, jak i dzikich, oraz człowiek.

Pasożyta opisano po raz pierwszy na początku XX w., kiedy to francuscy naukowcy, mikrobiolog Charls Jules Henry Nicolle i parazytolog Luis Herbert Manceaux, obaj pracujący w Instytucie Pasteura w Tunisie, wyizolowali tachyzoity $T$. gondii $z$ tkanek gryzonia, gundii zwyczajnej. Nazwa gatunkowa pasożyta została utworzona $z$ połaczenia greckich słów toxon - łuk oraz plasma - forma, nawiazujących do półksiężycowatego/łukowatego kształtu formy wegetatywnej pierwotniaka oraz $z$ nazwy zwierzęcia - gundii (gondii), u którego został po raz pierwszy wykryty (DUBEY 2009).

\section{FORMY INWAZYJNE PASOŻYTA}

W rozwoju T. gondii występują trzy formy inwazyjne:

- tachyzoity (gr. tachos, szybko) - formy wegetatywne pasożyta, które podlegaja intensywnym podziałom. Maja kształt półksiężyca, $z$ jednej strony zaokraglony, a $z$ drugiej ostro zakończony, o długości $6 \mu \mathrm{m}$ i szerokości $2 \mu \mathrm{m}$. Tachyzoity aktywnie penetrują błonę komórkowa i lokuja się w ko- mórkach jądrzastych żywiciela pośredniego lub w komórkach nabłonka jelita żywiciela ostatecznego, gdzie otaczaja się wakuola pasożytnicza, której zadaniem jest m.in. ochrona przed mechanizmami obronnymi żywiciela (DUBEy i współaut. 1998);

- bradyzoity (gr. brady- powoli) - formy spoczynkowe, powstajace w wyniku przemiany tachyzoitów. Skupiają się w cystach tkankowych, w których podlegaja powolnym podziałom. Kształtem i wielkościa przypominaja tachyzoity, sa nieco smuklejsze, o wymiarach $7,0 \times 1,5 \mu \mathrm{m}$. Cysty tkankowe otoczone sa własna, cienka, elastyczna ściana, następnie zostaja otoczone tkanką łączna żywiciela, a na koniec ulegaja wysyceniu solami wapnia. Ulokowane sa głównie w tkance nerwowej, w tym w mózgowiu i oku, w mięśniach poprzecznie prążkowanych: mięśniach szkieletowych i mięśniu sercowym, rzadziej w płucach, watrobie i nerkach. Cysty ulokowane w tkance nerwowej zazwyczaj sa owalne, o średnicy do $70 \mu \mathrm{m}$, natomiast w mięśniach sa podłużne do $100 \mu \mathrm{m}$ długości. W dojrzałych cystach moga znajdować się setki bradyzoitów (DUBEY i współaut. 1998);

- sporozoity w oocystach. Oocysty sa kulistymi formami dyspersyjnymi, o średnicy 10-12 $\mu \mathrm{m}$. Sa otoczone potrójna ściana, odporna na czynniki fizyczne i chemiczne, co umożliwia im przetrwanie w środowisku. Oocysty stają się inwazyjne dopiero po sporulacji, do której dochodzi w środowisku zewnętrznym, po 1-5 dniach od wydalenia wraz $z$ odchodami kota. Sporulowana oocysta (średnica 11-13 $\mu \mathrm{m}$ ) zawiera wewnątrz dwie elipsoidalne sporocysty, a w każdej sporocyście znajduja się cztery sporozoity (DUBEY i współaut. 1998). W sprzyjajacych 
warunkach oocysty sa zdolne do przeżycia w glebie oraz wodzie słodkiej i słonej nawet do 2 lat (LINDSAY i DUbey 2009, Simon i współaut 2013).

\section{LĄDOWY CYKL ŻYCIOWY T. GONDII}

Mimo że pasożyta poznano na początku $\mathrm{XX}$ w., przebieg jego cyklu życiowego ustalono dopiero w latach 70. XX w. (DUBEY 2009). Od tego czasu powstało wiele prac naukowych opisujacych przebieg lądowego cyklu życiowego $T$. gondii, $z$ uwzględnieniem lokalnych zależności pomiędzy żywicielami w różnych rejonach świata.

Zarażenie $T$. gondii stwierdzono u ponad 350 gatunków ptaków i ssaków na całym świecie, w tym także u człowieka (DuBEY 2002, ROBERT-GANGNEUX i DARDE 2012). Wśród żywicieli znajdują się m.in.: myszy, szczury, wiewiórki, niedźwiedzie, szopy pracze, lisy, króliki i zające, bobry, jeleniowate, dziki oraz wiele innych gatunków zwierząt występujacych lokalnie. Ze zwierzat towarzyszacych i hodowlanych najczęściej wymieniane ssaki to: koty, psy, fretki, norki, konie, owce, kozy, bydło, świnie, wielbłądy, lamy i alpaki, króliki oraz ptaki: indyki, kury, kaczki, gęsi i gołębie (LINDSAY i DUBEY 2014). Zarażenie $T$. gondii notowano także wśród dziko żyjacych ptaków, m.in. u przedstawicieli rzędu Galliformes (grzebiące) (w tym dzikie indyki, bażanty, kuropatwy), Anseriformes (blaszkodziobe) (różne gatunki kaczek i gęsi), Accipitriformes (szponiaste), Passeriformes (wróblowe), Columbiformes (gołębiowe), Strigiformes (sowy), Charadriiformes (siewkowe) i Gruiformes (żurawiowe) (DUBEY 2002, LINDSAY i DUBEY 2014).

Żywicielem ostatecznym T. gondii sa wyłącznie kotowate, zarówno udomowione, jak i dzikie. Kotowate najczęściej zarażaja się zjadając upolowane, zarażone gryzonie i ptaki, bądź, gdy sa karmione lub maja dostęp do surowego mięsa, choćby resztek poubojowych. W żołądku i jelicie cienkim enzymy proteolityczne rozpuszczają ścianę cysty tkankowej i następuje uwolnienie bradyzoitów, które penetruja do komórek nabłonka jelita cienkiego. Tam ulegaja przekształceniu w tachyzoity, które podlegaja licznym, szybkim podziałom. Kolejnym etapem jest gametogonia (rozmnażanie płciowe). Zapoczątkowuje ja powstanie schizontów, dzielących się następnie na merozoity. Część merozoitów rozwija się w gametocyty. W procesie sporogonii powstaja mikrogamety i makrogamety, które następnie łączą się i powstaje zygota, z której rozwija się oocysta. Niedojrzałe oocysty (niezdolne do zarażenia) sa uwalniane $z$ komórek nabłonka do światła jelita i wydalane do środowiska ze- wnẹtrznego wraz z kałem żywiciela ostatecznego. Zarażony kot wydala do środowiska miliony oocyst przez 1-2 tygodnie w życiu (Hill i Dubey 2002, Dubey i Jones 2008).

Oocysty staja się inwazyjne dla żywiciela pośredniego dopiero po sporulacji, która następuje w środowisku zewnętrznym, najczęściej w ciagu 1-5 dni od ich wydalenia (DUBEY i współaut. 1998).

Zwierzęta stałocieplne, zjadajace rośliny lub pijacce wodę zanieczyszczona oocystami, bądź spożywające mięso zawierające cysty tkankowe, stają się żywicielami pośrednimi. W organizmie żywiciela pośredniego sporozoity $z$ oocyst oraz bradyzoity $z$ cyst tkankowych ulegaja przekształceniu w tachyzoity. Tachyzoity intensywnie namnażają się w układzie siateczkowo-śródbłonkowym oraz $\mathrm{w}$ komórkach nabłonka jelita cienkiego, ską za pośrednictwem krwi i limfy rozprzestrzeniaja się do różnych tkanek i narządów. Intensywnie namnażające się tachyzoity powoduja pęknięcie zarażonej komórki i uwolnienie tachyzoitów, które zarażaja kolejne komórki. Po pewnym czasie następuje zahamowanie namnażania tachyzoitów, przekształcenie się ich w bradyzoity i wytworzenie cyst tkankowych, najczęściej w mięśniach szkieletowych i mózgowiu (RoBERT-GANGNEUX i DARDE 2012). U niektórych zwierzat, np. owiec, udokumentowano zarażenie wewnatrzmaciczne, mogace powodować obumieranie płodu, ronienia lub śmierć nowonarodzonych zwierzat (HILl i współaut. 2005, Dubey i Jones 2008).

\section{T. GONDII W ŚRODOWISKU MORSKIM}

Od kilkudziesięciu lat $\mathrm{w}$ wielu rejonach świata, od Arktyki po Antarktykę, zarażenia $T$. gondii sa coraz częściej notowane nie tylko wśród zwierząt lądowych, ale także wśród ssaków morskich. Objawy kliniczne toksoplazmozy opisano m.in. u kałanów, delfinów, morświnów, fok, morsów i manatów (LINDSAY i DUBEY 2014).

Szczególnie liczne zarażenia, $z$ przypadkami śmiertelnymi, obserwowane sa u kałanów kalifornijskich (Enhydra lutris nereis) ${ }^{1}$, powszechnie znanych jako wydry morskie, żyjących u wybrzeży Kalifornii, USA. Wzrost śmiertelności kałanów kalifornijskich zaobserwowano na początku lat 90. XX wieku. Pracownicy National Wildlife Health Center (NWHC), Madison, Wisconsin, USA przeprowadzili wówczas badania martwych zwierząt, starajac się ustalić przyczyny. Z tkanek części zwierząt, szczególnie $z$ mózgowia i serca, wyizolowano T. gondii. W warunkach labora-

${ }^{1} Z$ astosowano nazewnictwo polskie za: CicHOCKI i współaut., 2015. Polskie nazewnictwo ssaków świata. Muzeum i Instytut Zoologii PAN, Warszawa. 
toryjnych, $z$ wykorzystaniem myszy i kotów wykazano, że pasożyty pochodzace od kałanów kalifornijskich miały zdolność zarażania i produkcji oocyst (COLE i współaut. 2000). Podobnie, wysoka seroprewalencja (rozwój wykrywalnych, specyficznych, skierowanych przeciw mikroorganizmom przeciwciał w surowicy krwi) wystepuje u innego podgatunku, kałana morskiego E. lutris kenyoni, żyjącego na Wschodnim Wybrzeżu USA (CONRAD i współaut. 2005).

Dieta kałanów, składająca się $z$ bezkręgowców morskich, takich jak małże, ślimaki morskie, kraby i jeżowce (CONRAD i współaut. 2005), wyklucza możliwość zarażenia się cystami tkankowymi, które znajduja się jedynie w tkankach zwierzact stałocieplnych. Do zarażenia oocystami może dojść więc albo poprzez bezpośrednie połknięcie ich wraz $z$ zanieczyszczona woda, badź poprzez zjadanie bezkręgowców, szczególnie gatunków filtrujących, mogących kumulować oocysty w swoim organizmie (DUBEY i JONES 2008, Miller i współaut. 2008b). CONRAD i współaut. (2005) wskazuja na możliwość zarażania się kałanów również przez zebranie i połknięcie oocyst podczas czyszczenia futra.

Oocysty do środowiska morskiego moga dostać się $z$ lądu wraz $z$ dopływajacymi wodami rzek, ściekami bytowymi lub częściej poprzez spływ powierzchniowy, zwłaszcza w porze roztopów lub intensywnych opadów (SIMON i współaut. 2013, VANWORMER i współaut. 2016). Do zanieczyszczenia formami dyspersyjnymi środowiska lacdowego i dalej ekosystemów wodnych przyczyniaja się dzikie kotowate np. pumy, rysie, zdziczałe koty oraz w mniejszym stopniu koty udomowione (SIMON i współaut. 2013, VANWORMER i współaut. 2013a, 2016).

W środowisku morskim oocysty wychwytywane i kumulowane przez morskie bezkręgowce filtrujace, np. małże, moga być nastepnie transportowane do kolejnych ogniw łańcucha pokarmowego. Zdolność do bioakumulacji oocyst $z$ zanieczyszczonej wody przez bezkręgowce, $z$ zachowaniem inwazyjności, została potwierdzona w przypadku omułka kalifornijskiego, Mytilus californianus, omułka śródziemnomorskiego M. galloprovincialis, ostryg Crassostrea virginica (LINDSAY i współaut. 2001, 2004; ARCUSH i współaut. 2003), Crassostrea rhizophorae (ESMERINI i współaut. 2010) i słuchotek Haliotis rufescens (SCHOTT i współaut. 2016). T. gondii w warunkach naturalnych odnotowano w omułkach kalifornijskich (MILLER i współaut. 2008b) i ślimakach morskich $z$ rodzaju Chlorostoma i Promartynia (KRUSOR i współaut. 2015). ESMERINI i współaut. (2010) stwierdzili T. gondii w C. rhizophorae pochodzacych ze sklepu w Brazylii, a Putignani i współaut. (2011) w C. gigas i Tapes decussatus $z$ włoskich hodowli w Apulii.

LiNDSEY i współaut. (2001) wykazali że oocysty są w stanie przeżyć w ostrygach zachowując inwazyjność przez 6 dni. Z kolei ARKUSH i współaut. (2003) stwierdzili obecność żywych, zdolnych do inwazji oocyst u omułków do 3 dni, a ssrRNA T. gondii metoda PCR wykrywali do 3 tygodni od ekspozycji. W kolejnych badaniach LINDSEY i współaut. (2004), badając przeżywalność oocyst w ostrygach wykazali, że pochłonięte przez ostrygi sporulowane oocysty moga w nich przetrwać znacznie dłużej niż we wcześniejszych badaniach. W ostrygach oocysty były w stanie przetrwać nawet 85 dni, zachowujac inwazyjność przez 3 tygodnie. U myszy, które zostały nakarmione ostrygami eksponowanymi na oocysty do 21 dni wcześniej rozwijały się cysty tkankowe. U myszy karmionych ostrygami eksponowanymi ponad 3 tygodnie wcześniej, do rozwoju cyst tkankowych już nie dochodziło. Natomiast wykorzystując test aglutynacji mikroskopowej MAT, autorzy stwierdzali obecność przeciwciał przeciw T. gondii u myszy karmionych tkankami ostryg eksponowanych 85 dni wcześniej.

Zdolność do bioakumulacji oocyst została stwierdzona także u słodkowodnego skorupiaka, kiełża Gammarus fossarum (BIGOT-Clivot i współaut. 2016), co wskazuje że potencjalnie podobna zdolność moga posiadać także inne skorupiaki, w tym gatunki morskie.

Zarażenia T. gondii występuja także u ssaków morskich, które w przeciwieństwie do kałanów żywią się rybami. Tutaj możliwa droga zarażenia wydaje się zanieczyszczona woda lub ryby. Jednak np. delfiny pija mało wody lub nie pija wcale i najchętniej żywia się rybami, głowonogami lub innymi zwierzętami zmiennocieplnymi (PRETTI i współaut. 2010). Ryby, podobnie jak bezkręgowce, nie należa do żywicieli pośrednich, gdyż T. gondii pasożytuje wyłącznie u zwierzą stałocieplnych. Moga zatem być jedynie wektorami, jeśli sa w stanie bioakumulować w swoim przewodzie pokarmowym oocysty pobrane ze środowiska. MASSIE i współaut. (2010) w warunkach laboratoryjnych wykazali taka możliwość u ryb filtrujacych, jak sardela kalifornijska (Engraulis mordax) i sardynka pacyficzna (Sardinops sagax). Ryby te potencjalnie moga być wektorami zdolnych do inwazji oocyst T. gondii przez około 8 godzin od ekspozycji. W warunkach naturalnych takiej możliwości dotychczas nie potwierdzono (JONES i DUBEY 2010).

Poza kałanami morskimi $T$. gondii stwierdzano u wielu gatunków ssaków morskich na całym świecie, m.in. u Sousa chinensis 
(garbogrzbiet chiński), Stenella longirostris (delfinek długoszczęki), S. coeruleoalba (delfinek pręgoboki), Tursiops truncatus (butlonos zwyczajnyl, T. aduncus (butlonos indyjski), Delphinapterus leucas (białucha arktyczna), Balaenoptera physalus (płetwal zwyczajny), Grampus griseus (risso szary), Zalophus californianus (uszanka kalifornijska), Callorhinus ursinus (koticzak niedźwiedziowaty), Mirounga angustirostris (mirunga północna), Neomonachus schauinslandi ${ }^{2}$ (mniszka hawajska), Trichechus manatus (manat karaibski), Phoca vitulina (foka pospolita) (LINDSAY i DUBEY 2014), Odobenus rosmarus (mors arktyczny) (Simon i współaut. 2011), Halichoerus grypus (szarytka morska), Phoca largha (foka plamista), Pusa hispida (nerpa obraczkowana), Erignathus barbatus (fokowass brodaty), Cystophora cristata (kapturnik morski), Pagophilus groenlandicus (lodofoka grenlandzka) (CABEZÓN i współaut. 2011), Leptonychotes weddellii (weddelka arktyczna), Mirounga leonina (mirunga południowa) (JENSEN i współaut. 2012) oraz Phocarctos hookeri (maoryszanka uszata) (MicHAEL i współaut. 2016).-

T. gondii odnotowano u ssaków morskich w wodach wokół Europy, m.in. u wybrzeży Wielkiej Brytanii i Francji u takich gatunków jak: Delphinus delphis (delfin zwyczajny), Phocoena phocoena (morświn zwyczajny) oraz Megaptera novaeangliae (długopłetwiec oceaniczny), Phoca vitulina (foka pospolita) i Halichoerus grypus (szarytka morska) (FoRMAN i współaut. 2009, CABEZÓN i współaut. 2011), w Morzu Północnym u Phocoena phocoena (morświn zwyczajny) (VAN DEVELDE i współaut. 2016), w Morzu Śródziemnym u wybrzeży Hiszpanii u Stenella coeruleoalba (delfinek pregoboki), Delphinus delphis (delfin zwyczajny), Tursiops truncatus (butlonos zwyczajny), Phocoena phocoena (morświn zwyczajny), Grampus griseus (risso szary) i Globicephala melas (grindwal długopłetwy) (RESENDES i współaut. 2002, CABEZÓN i współaut. 2004) oraz w Morzu Tyrreńskim i Morzu Liguryjskim u Tursiops truncatus (butlonos zwyczajny) i Stenella coeruleoalba (delfinek pręgoboki) (PRETTI i współaut. 2010, Di GUARDO i współaut. 2010). W Oceanie Arktycznym przeciwciała przeciw $T$. gondii notowano u Pusa hispida (nerpa obraczkowa) i Erignathus barbatus (fokowas brodaty) (JENSEN i współaut. 2010).

Najwyższa prewalencja przeciwciał przeciw T. gondii notowana jest u kałanów morskich i waha się w zależności od regionu od $47 \%$ do 100\%. Wysoka seroprewalencja jest opisywana także u delfinów butlonosych w rejonie Kalifornii i Florydy (MILLER i współaut. 2002, Jones i DUBEY 2010) oraz foko-

${ }^{2}$ Autorzy stosują synonim Monachus schauinslandi. wąsów brodatych i nerp obraczkowanych w Arktyce (JENSEN i współaut. 2010).

U części zarażonych ssaków występuja objawy ze strony ośrodkowego układu nerwowego, zmiany zachowania, rzadziej poronienia, śmierć płodu i noworodków oraz toksoplazmoza wrodzona (JARDINE i DUBEY 2002, Miller i współaut. 2008a). W 2004 r. zaobserwowano przypadek zarażenia przezłożyskowego u kałana (MILLER i współaut. 2008a). Podobne przypadki znane sa u butlonosa indyjskiego (JARDINE i DUBEY 2002) i risso szarego (RESENDEs i współaut. 2002). Objawowa postać toksoplazmozy opisano u garbogrzbieta chińskiego, delfinka długoszczękiego, delfinka pręgobokiego i butlonosa zwyczajnego (DI GUARDO i współaut. 2010, LINDSAY i DUBEY 2014). Udokumentowane śmiertelne przypadki toksoplazmozy poza kałanami morskimi, dotycza butlonosów zwyczajnych (INSKEEP i współaut. 1990), fok pospolitych i uszanek kalifornijskich (LINDSAY i DUBEY 2014, CARLSON-BREMER i współaut. 2015). MichAEL i współaut. (2016) wskazuja, że zarażenie T. gondii może być powodem słabego sukcesu reprodukcyjnego obserwowanego u nowozelandzkich maoryszanek uszatych.

\section{WYSTEPOWANIE T. GONDII W SRODOWISKU MORSKIM A ZDROWIE ZWIERZAT I ZDROWIE PUBLICZNE}

Zanieczyszczenie wody chorobotwórczymi bakteriami, wirusami i formami dyspersyjnymi pasożytów jest ogólnoświatowym problemem dotyczacym zdrowia publicznego i zdrowia zwierzat (VANWORMER i współaut. 2013b). Występowanie T. gondii w środowisku wodnym stwarza lokalne problemy nie tylko dla zdrowia ssaków morskich, ale także dla polujących na nie niedźwiedzi polarnych w Arktyce (JENSEN i współaut. 2010). Martwymi fokami moga żywić się także inne, mniejsze drapieżniki, np. lisy polarne i ptaki drapieżne. W dalekiej Arktyce nie występuja kotowate, mogace przyczyniać się do zanieczyszczenia środowiska lądowego, a poprzez spływ powierzchniowy także środowiska morskiego, oocystami T. gondii (SIMON i współaut. 2011). Do rozprzestrzeniania pasożyta w ekosystemach arktycznych moga przyczyniać się ptaki, Branta leucopsis - bernikle białolice (JENSEN i współaut. 2010). Ptaki moga zarażać się na zimowiskach, m.in. u wybrzeży Morza Północnego i Morza Irlandzkiego, a po powrocie na obszary lęgowe stanowić, obok fok, źródło zarażenia dla lokalnej fauny. Nie tłumaczy to jednak możliwości zarażenia ssaków morskich w dalekiej Arktyce. W innych rejonach geograficz- 


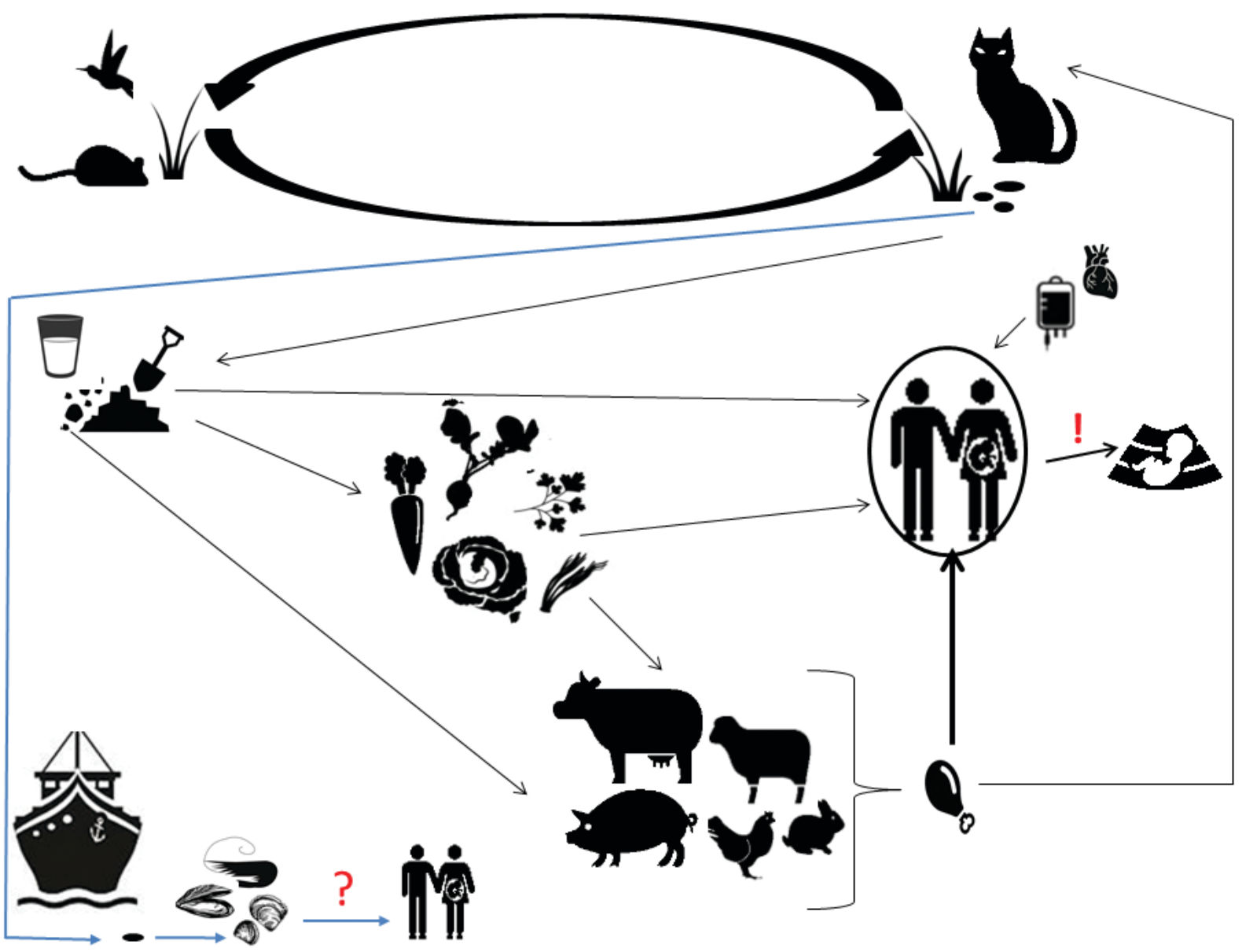

Ryc. 1. Źródła zarażenia człowieka Toxoplasma gondii.

nych spływ powierzchniowy stanowi najistotniejszy czynnik wpływajacy na zanieczyszczenie wody morskiej i możliwość zarażenia zwierzat morskich (SIMON i współaut. 2013; VANWORMER i współaut. 2013a, b, 2016).

Człowiek zaraża się $T$. gondOii przede wszystkim zjadajac surowe lub niedogotowane mięso zawierajace cysty tkankowe lub połykajacc oocysty wraz $z$ zanieczyszczona woda lub żywnościa (np. warzywa), rzadko poprzez transfuzję krwi lub transplantację narząów (Ryc. 1). Udokumentowane sa także wodnopochodne epidemie toksoplazmozy, zwiazane $z$ zanieczyszczeniem źródeł wody oocystami, m.in. w Kanadzie, Indiach, Brazylii czy Panamie (Tenter i współaut. 2000, Jones i Dubey 2010, RoBERT-GANGNEuX i DARDE 2012).

U większości osób dorosłych nie stwierdza się objawów klinicznych (DUBEY i JONES 2008, Jones i DUBEy 2010). Natomiast niebezpieczne jest pierwotne zarażenie w przypadku kobiet w ciąży, ze względu na możliwość wewnątrzmacicznego zarażenia płodu i wystapienia toksoplazmozy wrodzonej (DUBEY i JONES 2008, ROBERT-GANGNEUX i DAR-
DE 2012). Do grupy, u której moga wystąić objawy kliniczne należą także osoby $z$ niedoborami immunologicznymi, szczególnie chorujace na AIDS oraz leczone lekami immunosupresyjnymi (TENTER i współaut. 2000, ROBERT-GANGNEUX i DARDE 2012).

Występowanie $T$. gondii w ekosystemach morskich może stwarzać zarówno lokalne, jak i globalne problemy dla zdrowia publicznego. Przykładem lokalnych problemów moga być obszary arktyczne, gdzie zwyczaje zjadania surowego lub suszonego mięsa foczego i foczej wattroby, obok surowego mięsa karibu, oraz skórowania upolowanych zwierząt (np. lisów, wilków, kun) stanowia źródło zarażeń kanadyjskich Inuitów (TENTER i współaut. 2000; TENTER 2009; SIMON i współaut. 2011, 2013).

Morskie bezkręgowce, mięczaki i skorupiaki, stanowiace podstawę lub uzupełnienie diety ssaków morskich, znajdują się także w diecie ludzi (CONRAD i współaut. 2005). Bezkręgowce żyjące w strefie przybrzeżnej sa najbardziej narażone na wpływ zanieczyszczeń ze spływu powierzchniowego lub ścieków. Jeśli będą wykazywać zdolność prze- 
noszenia oocyst $z$ wody morskiej do człowieka, moga stać się globalnym problem zdrowia publicznego. PUTIGNANi i współaut. (2011), na podstawie badań mięczaków (w tym ostryg najczęściej spożywanych w stanie surowym) przeprowadzonych w hodowlach w Apulii we Włoszech uważaja, że spożywanie mięczaków morskich może stanowić zagrożenie zdrowia. Podobnie Jones i współaut. (2009) w swoim badaniu kliniczno-kontrolnym wskazują, że jedzenie surowych owoców morza: ostryg, omułków i innych mał$\dot{z} y$ stanowi nowe ryzyko zarażenia $T$. gondii w USA. Ewentualne ryzyko ze strony ryb filtrujacych, jak sardynka czy sardela, jest znikome, gdyż w przeciwieństwie do bezkręgowców, ryby przed spożyciem sa patroszone . Stąd ostrzeżenia, aby w rejonach, gdzie jest wysokie spożycie owoców morza, nie jeść ich na surowo, a dopiero po odpowiedniej obróbce termicznej. Szczególnie istotne jest, aby świadome potencjalnego zagrożenia były osoby $z$ grup ryzyka, czyli kobiety w ciąży, osoby $z$ niedoborami odporności i przyjmujące leki immunosupresyjne.

\section{PODSUMOWANIE}

Obecnie w wielu ekosystemach morskich, również w Arktyce i Antarktyce, stwierdzana jest obecność przeciwciał przeciw T. gondii lub objawowa toksoplazmoza u różnych gatunków ssaków morskich. Obecność $T$. gondii w środowisku morskim może stanowić także potencjalne ryzyko dla zdrowia ludzi. Wiedzę o biologii T. gondii należy poszerzać o rolę różnych gatunków zwierząt morskich w cyklu życiowym pasożyta oraz w jego transmisji. Istotne ze względu na zdrowie zwierząt i ludzi jest monitorowanie filtrujących bezkręgowców, jak również lepsze poznanie znaczenia spływu powierzchniowego w zanieczyszczeniu wody morskiej w różnych rejonach świata.

\section{Streszczenie}

Od końca lat 90. XX w. stwierdzane sa zrażenia $T$. gondii różnych gatunków ssaków morskich na całym świecie. Szczególnie liczne przypadki dotyczą kałanów morskich, w których diecie nie ma znanych żywicieli pierwotniaka, gdyż odżywiają się bezkręgowcami. Możliwość kumulowania przez filtrujące bezkręgowce oocyst i przekazywania ich do kolejnych ogniw łańcucha pokarmowego jest istotne nie tylko ze względu na krążenie pasożytów w środowisku naturalnym, ale może mieć znaczenie także dla zdrowia publicznego.

\section{LITERATURA}

ARKush K. D., Miller M. A., Leutenegger C. M., GARDNER I. A., PACKHAM A. E., HECKEROTH A. R., Tenter A. M., Barr B. C., Conrad P. A., 2003. Molecular and bioassay-based detection of Toxoplasma gondii oocyst uptake by mus- sels (Mytilus galloprovincialis). Int. J. Parasitol. 33, 1087-1097.

Bigot-Clivot A., Palos ladeiro M., Lepoutre A., Bastien F., Bonnard I., Dubey J. P., Villena I., Aubert D., GefFard O., François A., GeFFARD A., 2016. Bioaccumulation of Toxoplasma and Cryptosporidium by the freshwater crustacean Gammarus fossarum: Involvement in biomonitoring surveys and trophic transfer. Ecotoxicol. Environ. Saf. 133, 188-94.

Cabezón O., Resendes A. R., DOMingo M., Raga J. A., Agustí C., Alegre F., Mons J. L., DubeY J. P., Almería S., 2004. Seroprevalence of Toxoplasma gondii Antibodies in Wild Dolphins From the Spanish Mediterranean Coast. J. Parasitol. 90, 643-644.

CABEzón O., Hall A. J., Vincent C., PABON M., GARCIA-BOCANEGRA I., DUBEY J. P., ALMERIA S., 2011. Seroprevalence of Toxoplasma gondit in North-eastern Atlantic harbor seal (Phoca vitulina vitulina) and grey seal (Halichoerus grypus). Vet. Parasitol. 179, 253-256.

CARLson-Bremer D., Colegrove K. M., Gulland F. M. D., CONRAD P. A., MAZET J. A. K., JoHNSON C. K., 2015. Epidemiology and pathology of toxoplasma gondii in free-ranging california sea lions (Zalophus californianus). J. Wildlife Dis. 51, 362-373.

CICHOCKI W., WAŻNA A., CICHOCKI J., RAJSKA E., JASIŃSKI A., BOGDANOWICZ W., 2015. Polskie nazewnictwo ssaków świata. Muzeum i Instytut Zoologii PAN, Warszawa.

Cole R. A., Lindsay D. S., Howe D. K., Roderick C. L., Dubey J. P., Thomas N. J., BAeten L. A., 2000. Biological and molecular characterizations of toxoplasma gondii strains obtained from southern sea otters (Enhydra lutris nereis). J. Parasitol. 86, 526-530.

CONRAD P. A., Miller M. A., KREUder C., JAMES E. R., MAZET J., DABRiTZ H., Jessup D. A., Gulland F., GRIGG M. E., 2005. Transmission of Toxoplasma: Clues from the study of sea otters as sentinels of Toxoplasma gondii flow into the marine environment. Int. J. Parasitol. 35, 1155-1168.

Di Guardo G., Proietto U., Di Francesco C. E., MARSILIO F., ZACCARONI A., SCARAVELLI D., MIGNONE W., GaRibaldi F., KenNedy S., Forster F., Iulini B., BozzetTa E., CASAlone C., 2010. Cerebral toxoplasmosis in striped dolphins (Stenella coeruleoalba) stranded along the $\mathrm{Li}$ gurian Sea coast of Italy. Vet. Pathol.47, 245253.

DUBEY J. P., 2002. A review of toxoplasmosis in wild birds. Vet. Parasitol. 106, 121-153.

DuBEY J. P., 2009. History of the discovery of the life cycle of Toxoplasma gondii. Int. J. Parasitol. 39, 877-882.

DUBEY J. P., JONES J. L., 2008. Toxoplasma gondii infection in humans and animals in the United States. Int. J. Parasitol. 38, 12571278.

DubeY J. P., Lindsay D. S., Speer C. A., 1998. Structures of Toxoplasma gondii tachyzoites, Bradyzoites, and sporozoites and biology and development of tissue cysts. Clin. Microbiol. Rev. 11, 267-299.

Esmerini P. O., Gennari S. M., Pena H. F. J., 2010. Analysis of marine bivalve shellfish from the fish market in Santos city, Sao Paulo state, Brazil, for Toxoplasma gondii. Vet. Parasitol. $170,8-13$

FORMAN D., WEST N., FRANCIS J., GuY E., 2009. The sero-prevalence of Toxoplasma gondii in British marine mammals. Mem Inst Oswaldo Cruz, Rio de Janeiro 104, 296-298. 
Hill D. E., DuBEY J. P., 2002. Toxoplasma gondii: transmission, diagnosis and prevention. Clin. Microbiol. Infect. 8, 634-640.

Hill D. E., ChiRukandoth S., DuBey J. P., 2005. Biology and epidemiology of Toxoplasma gondii in man and animals. Anim. Health. Res. Rev. 6, 41-61.

Inskeep W., Gardiner C. H., HaRris R. K., DUBey J. P., Goldston R. T., 1990. Toxoplasmosis in Atlantic Bottle-Nosed Dolphins (Tursiops truncatus). J. Wildlife Dis. 26, 377-382.

JARDINE J. E., DUBEY J. P., 2002. Congenital toxoplasmosis in Indo-Pacific bottlenose dolphin (Tursiops aduncus). J. Parasitol. 88, 197-199.

JENSEN S.-K., AARS J., LYDERSEN C., KOVACS K. M., ASBAKK K., 2010. The prevalence of Toxoplasma gondii in polar bears and their marine mammal prey: Evidence for a marine transmission pathway? Polar Biol. 33, 599-606.

JENSEN S.-K., I. NYMO H., FORCADA J., GODFROID J., HAll A., 2012. Prevalence of Toxoplasma gondii antibodies in pinnipeds from Antarctica. Vet. Rec. 171, 249-250.

Jones J. L., Dargelas V., Roberts J., Press C., Remington J. S., MONTOYA J. G., 2009. Risk factors for Toxoplasma gondii infection in the United States. Clin. Infect. Dis. 49, 878-84.

JONES J. L., DUBEY J. P., 2010. Waterborne toxoplasmosis - Recent development. Exp. Parasitol. 124, 10-25.

Krusor C., Smith W. A., Tinker M. T., Silver M., CONRAD P. A., SHAPIRO K., 2015. Concentration and retention of Toxoplasma gondii oocysts by marine snails demonstrate a novel mechanism for transmission of terrestrial zoonotic pathogens in coastal ecosystems. Environ. Microbiol. 17, 4527-4537.

LINDSAY D. S, DUBEY J. P., 2009. Long-term survival of Toxoplasma gondii sporulated oocysts in seawater. J. Parasitol. 95, 1019-1020.

LindSAY D. S., DUBEY J. P., 2014. Toxoplasmosis in wild and domestic animals. Chapter 6. [W:] Toxoplasma gondii The Model Apicomplexan Perspectives and Methods. WEISS L. M., KIM K. (red.) Academic Press, 193-215.

Lindsay D. S., Phelps K. K., SMith S. A., Flick G., Sumner S. S., DUBEY J. P., 2001. Removal of Toxoplasma gondii oocysts from sea water by Eastern Oysters (Crassostrea virginica). J. Eukaryot. Microbiol. 48, 197s-198s.

Lindsay D. S., Collins M. V., Mitchell S. M., Wetch C. N., Rosypal A. C., Flick G. J., ZAJAC A. M., LINDQUisT A., DUBEY J. P., 2004. Survival of Toxoplasma gondii oocysts in eastern oysters (Crassostrea virginica). J. Parasitol. 90, 1054-1057.

Massie G. N., Ware M. W., Villegas E. N., Black M. W., 2010. Uptake and transmission of Toxoplasma gondii oocysts by migratory, filter-feeding fish. Vet. Parasitol. 169, 296-303.

Michael S. A., Howe L., Chilvers B. L., MOREL P. C. H., RoE W., 2016. Seroprevalence of Toxoplasma gondii in mainland and sub-Antarctic New Zealand sea lion (Phocarctos hookeri) populations. New Zeal. Vet. J. 64, 293-297.

Miller M. A., GaRDNER I. A., KREUder C., Paradies D. M., Worcester K. R., Jessup D. A., DODD E., HARRIS M. D., AMES J. A., PACKHAM A. E., CONRAD P. A., 2002. Coastal freshwater runoff is a risk factor for Toxoplasma gondii infection of southern sea otters (Enhydra lutris nereis). Int. J. Parasitol. 32, 997-1006.

Miller M. A., ConRad P., James E. R., PACKHAM A., TOY-CHOUTKA S., MURRAY M. J., JESSUP D., GRIGG M., 2008a. Transplacental toxoplas- mosis in a wild sea otter (Enhydra lutris nereis). Vet. Parasitol. 153, 12-18.

Miller M. A., Miller W. A., ConRad P. A., James E. R., Melli A. C., Leutenegger C. M., DABRITZ H. A., PACKham A. E., PARAdies D., HARRIS M., AMES J., JESSUP D. A., WORCESTER K., GRIGG M. E., 2008b. Type X Toxoplasma gondii in a wild mussel and terrestrial carnivores from coastal California: new linkages between terrestrial mammals, runoff and toxoplasmosis of sea otters. Int. J. Parasitol. 38, 1319-1328.

PretTi C., Mancianti F., NARDONi S., ARITI G., Monni G., Di Bello D., Marsili S., PAPINI R., 2010. Detection of Toxoplasma gondii infection in dolphins stranded along the Tuscan coast, Italy. Rev. Méd. Vét. 161, 428-431.

Putignani L., Mancinelli L., Del Chierico F., MENiChella D., ADlerstein D., ANGEliCI M. C., Marangi M., Berrilli F., CAFFara M., Frangipane Di REgalbono D. A., Giangaspero A., 2011. Investigation of Toxoplasma gondii presence in farmed shellfish by nested-PCR and real-time PCR fluorescent amplicon generation assay (FLAG). Exp. Parasitol. 127, 409417.

Resendes A. R., Almeria S., Dubey J. P., OBon E., Juan-Salles C., Degollada E., Algre F., CABEZÓN O., PONT S., DOMINGO M., 2002. Disseminated toxoplasmosis in a Mediterranean pregnant Risso's dolphin (Grampus griseus) with transplacental fetal infection. J. Parasitol. 88, 1029-1032.

RoberT-GangNeuX F., DARDE M. L., 2012. Epidemiology of and diagnostic strategies for toxoplasmosis. Clin. Microbiol. Rev. 25, 264-296.

SCHOTT K. C., KRUsor C., TINKER M. T., MOORE J., CONRAD P. A., SHAPIRO K., 2016. Concentration and retention of Toxoplasma gondii surrogates from seawater by red abalone (Haliotis rufescens). Parasitology 143, 1703-1712.

SimON A., CHAMBELlan T. M., WARD B. J., SimARD M., ProulX J. F., Levesque B., Bigras-Poulin M., Rousseau A. N., OGden N. H., 2011. Spatio-temporal variations and age e $\square$ ect on Toxoplasma gondii seroprevalence in seals from the Canadian Arctic. Parasitology 138, 1362-1368.

Simon A., Poulin M. B., Rousseau A. N., OGden N. H., 2013. Fate and transport of Toxoplasma gondii oocysts in seasonally snow covered watersheds: a conceptual framework from a melting snowpack to the Canadian Arctic Coasts. Int. J. Environ. Res. Public Health 10, 994-1005

TENTER A. M., 2009. Toxoplasma gondii in animals used for human consumption. Mem. Inst. Oswaldo Cruz 104, 364-369.

Tenter A. M., Heckeroth A. R., Weiss L. M., 2000. Toxoplasma gondii: from animals to $\mathrm{hu}$ mans. Int. J. Parasitol. 30, 1217-1258.

VAN DE Velde N., DeVleEsschauwer B., LeOPOlD M., BEgEMAN L., IJSSELDIJK L., HIEMSTRA S., IJZER J., BROWNLOW A., DAVISON N., HaElTERS J., JaUniauX T., SiEBert U., DORNY P., DE CRAEYE S., 2016. Toxoplasma gondii in stranded marine mammals from the North Sea and Eastern Atlantic Ocean: Findings and diagnostic difficulties. Vet. Parasitol. 230, 2532 .

VAnwormer E., CONRAD P. A., Miller M. A., MElli A.C., CARPENTER T. E., MAZET J. A. K., 2013a. Toxoplasma gondii, source to sea: higher contribution of domestic felids to terrestrial parasite loading despite lower infection prevalence. EcoHealth 10, 277-289. 
VANWORMER E., FRITZB H., SHAPIROA K., MAZETA J. A. K., CONRAD P. A., 2013b. Molecules to modeling: Toxoplasma gondii oocysts at the human-animal-environment interface. Comp. Immunol. Microbiol. Infect. Dis. 36, 217-231.
VANWORMER E., CARPEnter T. E., Singh P., SHAPIRO K., WALlENDER W. W., CONRAD P. A., LARGieR J. L., MANETA M. P., MAZET J. A. K., 2016. Coastal development and precipitation drive pathogen flow from land to sea: evidence from a Toxoplasma gondii and felid host system. Sci. Rep. 6, 29252.

KOSMOS Vol. 68, 3, 421-428, 2019

\author{
JolANTA MOROZIŃSKA-GOGOL
}

Faculty of Health Sciences, Pomeranian University in Słupsk, 64 Bohaterów Westerplatte Str., 76-200 Słupsk, E-mail: jolanta.

morozinska-gogol@apsl.edu.pl

\title{
TOXOPLASMA GONDII IN MARINE ENVIRONMENT
}

\section{Summary}

Since the end of the 1990s, many marine mammals are infected with T. gondii worldwide. Many cases of infection are related to sea otter. Because sea otters do not eat vertebrates, invertebrates are the possible route of infection. The possibility of accumulating oocysts by filtering invertebrates and transferring them to the next level of the food chain is important because of the circulation of parasites in the natural environment and also for public health.

Key words: Toxoplasma gondii, marine mammals, marine environment, public health 